\title{
International Postgraduate Students' Perception of Challenges in Academic Writing in Malaysian Public Universities
}

\author{
Sedigheh Shakib Kotamjani ${ }^{1 *}$, Arshad Abd Samad², Mehrnaz Fahimirad ${ }^{3}$ \\ ${ }^{1}$ Department of ELC, Shinas College of Technology, PO box 77, Shinas, Sultanate of Oman \\ ${ }^{2}$ Faculty of Educational Studies, Universiti Putra Malaysia, 43400 Serdang Selangor, Malaysia \\ ${ }^{3}$ Centre for Research \& Innovation in Tourism, Taylors University Lakeside Campus, 47500 Subang Jaya, Selangor, Malaysia
}

Corresponding Author: Sedigheh Shakib Kotamjani, E-mail: sedigheh.shakib@shct.edu.om

\section{ARTICLE INFO}

Article history

Received: July 12, 2018

Accepted: October 05, 2018

Published: December 01, 2018

Volume: 7 Issue: 7

Advance access: October 2018

Special Issue on Language \&

Literature

Conflicts of interest: None

Funding: None

\begin{abstract}
The purpose of this study is to investigate international postgraduate students' perceptions of difficulty with academic writing in Malaysian public universities. A survey was used to collect students' perceptions of difficulties and challenges in general academic writing skills and language-related skills. The results revealed that students perceived greater difficulty in languagerelated problems than general academic writing skills. In terms of language-related skills, they ranked writing coherent paragraph, summarizing and paraphrasing, applying appropriate lexical phrases, utilizing proper academic language and vocabulary respectively as the most difficult areas in writing. However, with respect to general academic writing skills, they perceived the most difficulties in reviewing and criticizing the literature, writing introduction and research gap. The results of this study implied that international postgraduate students who graduated from non-English medium instruction universities should be supported in terms of English for Academic Purposes (EAP), critical thinking skills and language-related skills to become selfdirected in learning to write.
\end{abstract}

Key words: Academic Writing, Difficulty, Challenges, Higher Educa

\section{INTRODUCTION}

Many international students with diverse linguistic and cultural backgrounds have been admitted into higher education institutions around the world (Hyland, 2008). They are expected to cope with the demands of their studies; and the style of living in a foreign country. One of the crucial requirements for international students is to be competent in English academic writing (Pecorari, 2006). Postgraduate students are supposed to conduct their research and report the research findings in the form of a dissertation/thesis and disseminate the findings to society via publication in leading journals.

In the current literature, second language writing has been investigated from two essential theoretical viewpoints: cognitive and socio-cultural (Kobayashi \& Rinnert, 2013). The cognitive perspective emphasizes on writing and revising processes, while the socio-cultural perspective emphasizes the product of writing for a certain audience. (Hartley, 2014). The level of students' writing competency can be affected by different factors such as L2 proficiency, the level of ability in L1 writing, and both writing experiences in L1 and L2 (Kobayashi \& Rinnert, 2013). Some studies suggested that first language writing ability is the main determinant of students' second language writing performance
(Kobayashi \& Rinnert, 2013; Petrić \& Czárl, 2003). It has been presumed that writing skill is transferred from L1 and L2 (Kobayashi \& Rinnert, 2013). Therefore, difficulties in L2 writing can be attributed to L1 writing difficulties. Conversely, other scholars argued that even though some writing strategies are common between L1 and L2, they are basically different (Petric \& Czarl, 2003). Consequently, L2 writing development depends on the amount of exposure and experiences in L2 rather than transferring cultural and rhetorical features from L1.

In terms of academic writing, students are required to integrate special skills including reviewing the related literature, organizing ideas into logical order, paraphrasing, summarizing, and proofreading (Elton, 2010). Postgraduate students are expected to search for related information on databases, read those related articles, summarize and compare the result of previous studies effectively. Furthermore, postgraduate students need to use proper academic vocabularies compatible with the style of academic writing and effective organizational skills in their writing.

Many ESL students consider writing as challenging task and they feel apprehensive about academic writing and thus, refuse to spend time on writing. At the tertiary level, the problems of writing difficulty can become more critical since students are required to write about the intellectual boundar- 
ies of their disciplines and their specific areas of expertise. Hence, the skill of academic writing seems to be challenging for international ESL students; they do need a lot of practice to master. The skill of English writing demands not only detailed knowledge about the subject and great linguistic competence but also writing skills and confidence (Saadiyah Darus, 2008). Particularly, doctoral students are required to involve actively in academic writing. Students are required not only write a dissertation to meet the degree requirements, but also they contribute to their discipline by publishing papers in their field of studies (Kamler \& Thomson, 2006b). Moreover, the quality and quantity of published papers improve the students' career and increase the universities' reputation and ranking.

In terms of difficulties in academic writing, Evans \& Green, (2007) reported that previous research has verified that L2 students perceived academic writing as a difficult task; however, these research dealt with the macro level of academic writing competency rather than the micro level. The results of Evans and Green's (2007) study revealed that students perceived language related skills as more difficult than content-related problems. Language related problems deal with difficulties in recording and conveying ideas appropriately and smoothly, whereas content related problems include writing methodology, introduction, references, and conclusion. The results of their study supported other studies such as Bitchener \& Basturkmen, (2006) and Ankawi, (2015) in which learners encounter difficulties in organizing ideas and arguments, expressing thought smoothly with appropriate styles of academic writing. Conversely, other studies (Marshall, 1991; Cai, 2013) revealed various results. They found that students might encounter more difficulties with organizing the structure and content of a paper more than the language-related problems.

According to Riji and Tajoddin (2013) the task of completing a written assignment on a content area was not challenging for students with high level of language proficiency in terms of task achievement, analyzing and critiquing the literature. In contrast, students with lower level of language proficiency provided extensive literatures which were not coherent and critical. They were unable to comprehend the rationale and arguments in their writing research. In another study, Noriah Ismail et al. (2008) conducted a study among 200 UITM students and analysed the students' revised drafts and identified their perceived writing difficulties. They found that the students' face difficulties not only in the language but also content. Students were not able to compose an in-depth and interesting content (Noriah Ismail et al. 2008). Therefore, based on their need analysis, students required more instructions not only for grammar instruction but also for idea development.

This inability can be largely attributed to their lack of proficiency in the English language. They found that students were trained to acquire knowledge through rote learning rather than through critical thinking (Kamler \& Thomson, 2006a). In addition, most international EFL students prefer to record their thoughts in their mother tongue. They translate what they understood from their mother tongue into English. Several supervisors reported that the majority of doc- toral students encountered difficulties in academic writing. Particularly, they encountered difficulties to develop and express ideas clearly and coherently (Bitchener \& Basturkmen, 2006).

Malaysian public universities have been receiving a large number of international students from different countries such as Iran, Iraq, Syria, Yemen, Pakistan, Saudi Arabia, Uzbekistan, Nigeria, and Sudan. In 2008, the Malaysian Ministry of Higher Education announced that all foreign students must meet the requirement of English language proficiency such as IELTS and TOEFL to continue their postgraduate studies (Riji, Tajuddin, \& Ahmad, 2013). In the existing literature, different results are presented concerning academic writing difficulties of L2 learners (Bitchener \& Basturkmen, 2006; Evans \& Green, 2007; Cai, 2013; Ankawi, 2015). Moreover, in the context of Malaysian universities, some studies have reported that in Malaysian universities international graduate students struggled in reading and writing practices (Ibrahim, \& Nambiar, 2011; Kaur, S., 2007; Shakib, 2017; Kaur, et al., 2009). They highlighted that the students in their home country are not prepared for the rigors of academic writing.

However, much less is known about international doctoral students' difficulties with academic writing in Malaysian universities in the current literature. Hence, this paper intends to examine international postgraduate students' perceptions of difficulty and challenges with English academic writing to describe need analysis in English academic writing at Universiti Putra Malaysia and Universiti Technology Malaysia as leading research universities in higher education institutes in Malaysia. This research aims to address the following research question:

What are the international postgraduate students' perceptions of problems and difficulties in academic writing?

\section{METHOD}

\section{Research Design}

To investigate international students' perceived difficulties in academic writing, a survey was employed. The researcher distributed 150 surveys among postgraduate international students in UPM and UTM libraries. Only 128 students returned and completed the survey. Descriptive statistics were used to describe the degree of international students' perception of difficulties in academic writing.

The participants of this study were 128 international postgraduate students who were studying in different fields of study at Universiti Putra Malaysia and Universiti Technology Malaysia. The level of their English proficiency ranged from intermediate to upper intermediate.

\section{Instrument}

To investigate international postgraduate students' perceived difficulties in academic writing, Evans \& Green's, survey (2007) was adapted in terms of 17 components of academic writing skills. There were 17 essential academic writing skills included in the survey, international postgraduate 
students demonstrated their perceived difficulty on a likerttype scale which ranged from 1 (very easy) to 5 (very difficult). Furthermore, the essential skills were categorized into two parts: the first was associated to general academic writing and the second part related to language related problems. The data gathered from the questionnaire were tabulated and analysed descriptively.

\section{RESULTS}

The findings of this study revealed that international postgraduate students experience greater difficulty in language-related problems $(M=64.19)$ than those of general academic skills $(\mathrm{M}=41.89)$. The reason is that postgraduate students are exposed to authentic content material in their field of studies; therefore, they face less difficulty with English content-related materials. Table 1 describes their responses to various skills and how difficult they perceived the skill to be.

When students are asked to rank the most problematic academic writing areas in which the students prefer to learn the most, the majority of the respondents $(68 \%)$ selected the ability to write critically and be inquisitive and critical of their writing process as their first choice, followed by their difficulties in writing introduction and research gap (66\%), research gap (61\%), writing conclusion (53\%), and discussing on the data $(51 \%)$ as the most challenging parts of general academic skills. This finding shows that the students stated that the ability to be critical when writing their thesis is the major problem and thus, they prefer to improve most in this area. In contrast, they experience less difficulty in writing references, referring sources and designing research method; particularly writing references and referring sources were the easiest skills.

However, international postgraduate students' perceptions differed noticeably in language-related problems as they found the following areas as the most challenging skills: writing coherent paragraph $(73 \%)$, summarizing and paraphrasing (71\%), applying appropriate lexical phrases $(68 \%)$, utilizing proper academic language and vocabulary $(66 \%)$, the proper grammar such as correct tenses, agreements, reporting verbs (59\%). In general, the students considered general academic writing skills as less difficult than the language related abilities.

\section{DISCUSSION}

The results of this study were consistent with the findings of studies by Evans and Green, 2007; Al-Tamimi \& Shuib, 2009; Lee \& Tajino, 2008) who conducted studies on non-native English-speaking undergraduates. They found that academic writing competency was considered very important for students' academic literacy. Based on the literature review, the results of this study was in line with Evans and Green's study (2007) who conducted a study to identify undergraduate students' difficulties in Hong Kong. They found that most students encounter difficulties with language-related problems and they have lower confidence to solve these language-related problems. Likewise, other studies reported same findings in EAP research (Lee \& Tajini, 2008; Hinkel, 2003) they found that students perceived some difficulties in terms of lexical and stylistic aspects of academic writing.

Table 1. Means of perceived difficulty of academic writing skills

\begin{tabular}{|c|c|c|}
\hline & Skills & $\%$ \\
\hline \multirow[t]{10}{*}{ General academic writing skills $(M=41.89)$} & "Writing introduction & 68.57 \\
\hline & Writing research gap" & 61.20 \\
\hline & "Searching for proper literature using databases and library resources" & 23.43 \\
\hline & "Referring to sources" & 15.62 \\
\hline & $\begin{array}{l}\text { "Reviewing and critiquing the previous research and creating a research } \\
\text { space (gap)" }\end{array}$ & 68.57 \\
\hline & "Designing the research methods" & 42.18 \\
\hline & "Summarizing and presenting the data" & 35.15 \\
\hline & "discussions on the data" & 51.56 \\
\hline & "Writing references/bibliography" & 1.76 \\
\hline & "Writing conclusions" & 53.12 \\
\hline \multirow[t]{7}{*}{ Language-related problems $(\mathrm{M}=64.19)$} & $\begin{array}{l}\text { "Understanding the specific language features of the academic } \\
\text { genre (such as writing research paper" }\end{array}$ & 40.62 \\
\hline & $\begin{array}{l}\text { "Using appropriate lexical phrases (such as on the basis of, it should be } \\
\text { noted that) freely to build sentences and paragraphs" }\end{array}$ & 68.87 \\
\hline & Summarizing/paraphrasing & 71.78 \\
\hline & Writing coherent paragraphs & 73.71 \\
\hline & Linking sentences smoothly & 68.75 \\
\hline & Using proper "academic" language and vocabulary (style) & 66.40 \\
\hline & $\begin{array}{l}\text { Using the proper grammar such as correct tenses, agreements, reporting } \\
\text { verbs }\end{array}$ & 59.20 \\
\hline
\end{tabular}


Unlike the results of this study, Jing Cai (2013) conducted a study to identify English major students' needs in academic writing. The results revealed that students perceived more difficulties in general academic skills than language related problems. This result could be attributed to the reason that those students majored in teaching English.

The findings of this study is supported by Noriah Ismail, et al., (2012) who investigated ESL tertiary students' writing problems in MARA university of Technology. They conducted a survey to identify students' needs in writing. They found that the students had problems with regards to writing critically and were not able to produce an in-depth writing in terms of content.

\section{CONCLUSION}

This study aimed to identify international postgraduate students' challenges in academic writing in public Malaysian universities. International postgraduate students encounter greater difficulties with language-related problems than those of general academic skills. In terms of general academic writing skills, they encountered more difficulty in writing critically to criticize the literature, writing introduction, as well as writing conclusion and discussing on data. Moreover, in terms of language related problems they had higher difficulties in writing coherent paragraphs, summarizing and paraphrasing, using appropriate lexical phrases, using proper academic language and vocabulary.

Students at the postgraduate level generally associate their perceptions of difficulty to their level of English proficiency. These difficulties could partly be traced back to methods and curriculum of teaching English in their home countries. The possible solution for these students and students in EFL context with the same problems is to teach them EAP genre-based pedagogy and provide them with language reference resources. To this end, instructors in English departments might develop new teaching materials in EAP, ESP and critical thinking courses to meet the students' thinking skills and linguistic needs. It is implied that higher education institutes in Malaysia might provide students with appropriate writing resources to foster academic writing skills and encourage students to become more critical in their writing process.

\section{ACKNOWLEDGMENTS}

This paper is based on a part of a research project which is funded by Universiti Putra Malaysia. The researchers would like to express their gratitude for the financial support provided by UPM. I would like to thank Dr. Arshad Abd Samad for collaborating in this project.

\section{REFERENCES}

Ankawi, A. (2015). The academic writing challenges faced by Saudi students studying in New Zealand School of Culture and Society. MA Thesis.

Bitchener, J., \& Basturkmen, H. (2006). Perceptions of the difficulties of postgraduate L2 thesis students writ- ing the discussion section. Journal of English for Academic Purposes, 5(1), 4-18. https://doi.org/10.1016/j. jeap.2005.10.002

Cai, L. J. (2013). Students' perceptions of academic writing: A needs analysis of EAP in China. Language Education in Asia, 4(1), 5-22. https://doi.org/http://dx.doi. org/10.5746/LEiA/13/V4/I1/A2/Cai

Elton, L. (2010). Academic writing and tacit knowledge. Teaching in Higher Education, 15(2), 151-160. https:// doi.org/10.1080/13562511003619979

Evans, S., \& Green, C. (2007). Why EAP is necessary: A survey of Hong Kong tertiary students. Journal of English for Academic Purposes, 6(1), 3-17. https://doi. org/10.1016/j.jeap.2006.11.005

Hartley, J. (2014). Academic Writing and Publishing. Igarss 2014. https://doi.org/10.1007/s13398-014-0173-7.2

Hinkel, E. (2003). Adverbial markers and tone in L1 and L2 students' writing. Journal of Pragmatics, 35(7), 1049 1068. https://doi.org/10.1016/S0378-2166(02)00133-9

Hyland, K. (2008). Writing theories and writing pedagogies. Indonesian Journal of English Language Teaching, 4(2), 91-110.

Ibrahim, N., \& Nambiar, R. (2011). Writing in Foreign Lands: The Case of Postgraduate International Students and the Introductory Sections of a Project Paper. Social and Behavioral Sciences, (18), 626-632.

Kamler, B., \& Thomson, P. (2006a). Doctoral writing: pedagogies for work with literatures. Elements, (April), 1-13. https://doi.org/10.1080/01580370802439870

Kamler, B., \& Thomson, P. (2006b). Helping doctoral students write: Pedagogies for supervision. Education, 2006, 154-157. https://doi.org/10.4324/9781315813639

Kaur, S., \& Shakila A. M. (2007). The Learning Experience of Postgraduate Students: Emergent Themes. (IPPTN) Bulletin of National Higher Education Research Institute, (9), 26-28.

Kaur, Sarjit \& Sidhu, G. K. (2009). A Qualitative Study of Postgraduate Students' Learning Experiences in Malaysia. International Education Studies, 2(3), 47-56.

Kobayashi, H., \& Rinnert, C. (2013). L1/L2/L3 writing development: Longitudinal case study of a Japanese multicompetent writer. Journal of Second Language Writing, 22(1), 4-33. https://doi.org/10.1016/j.jslw.2012.11.001

Marshall, S. (1991). A genre-based approach to the teaching of report-writing. English for Specific Purposes, 10(1), 3-13. https://doi.org/10.1016/0889-4906(91)90012-L

Mohd Riji, H., Syed Tajuddin, S. H., \& Ahmad, S. (2013). Postgraduate Student-Supervisor Interface : Issues and Challenges. Pertanika Journals, 21(2), 503-516.

Noriah Ismail, Supyan Hussin and Saadiyah Darus. 2012. ESL Tertiary Students' Writing Problems and Needs: Suggested Elements for an Additional Online Writing Program (IQ-Write) for the BEL 311 Course The international journal of learning.18(19): 69-78.

Pecorari, D. (2006). Visible and occluded citation features in postgraduate second-language writing. English for Specific Purposes, 25(1), 4-29. https://doi.org/10.1016/j. esp.2005.04.004 
Petrić, B., \& Czárl, B. (2003). Validating a writing strategy questionnaire. System, 31(2), 187-215. https://doi. org/10.1016/S0346-251X(03)00020-4

Saadiyah Darus. 2008. A Framework for a Computer-Based Essay Marking System: Specifically, Developed for ESL Writing. Germany: Lambert Academic Publishing.
Shakib, S. \& Habsah H. (2017). Perceptions of Challenges in Writing Academically : Iranian Postgraduate Students ' Perspectives, 6(4), 2013-2016. https://doi.org/10.7575/ aiac.ijalel.v.6n.4p.1

Turner,M.(2011).TheLiteraryMind.TheLiteraryMind.https:// doi.org/10.1093/acprof: oso/9780195126679.001.0001 